\title{
FOSTERING THE REDUCTION OF ASSORTATIVE MIXING OR HOMOPHILY INTO THE CLASS
}

\author{
Jaime Meza ${ }^{1}$, Oswaldo Ortiz ${ }^{2}$, Ester Simón ${ }^{1}$, Monica Vaca Cardenas ${ }^{3}$ Sonia \\ Román ${ }^{2}$, Josep Monguet ${ }^{1}$ \\ ${ }^{1}$ Universitat Politécnica de Catalunya (SPAIN) \\ ${ }^{2}$ Universidad de las Fuerzas Armadas - ESPE (ECUADOR) \\ ${ }^{3}$ Kansas State University (UNITED STATES)
}

\begin{abstract}
.
Human societies from the outset have been associated according to race, beliefs, religion, social level, and the like. These behaviors continue even today in the classroom at primary, middle, and superior levels. However, the growth of ICT offers educational researchers new ways to explore methods of team formation that have been proven to be efficient in the field of serious games through the use of computer networks. The selection process of team members in serious games with the use of computer networks is carried out according to their performance in the area of the game without distinction of social variables.
\end{abstract}

The use of serious games in education has been discussed in multiple research studies, which state that its application in teaching and learning processes are changing the way of teaching. This article presents an exploratory analysis of the team formation process based on collaboration with ICT tools of collective intelligence labelled The best team (TBT). The process and its ICT tool combine the paradigms of creativity in swarming, collective intelligence, serious games, and social computing in order to capture the participants' emotions and evaluate contributions.

Based on the results, we consider that the use of new forms of teaching and learning based on the emerging paradigms is necessary. Therefore, TBT is a tool that could become an effective way to encourage the formation of work groups by evaluating objective variable of performance of its members in collaborative works.

Keywords: collective intelligence, ICT, education, group formation.

\section{INTRODUCTION}

We live in families, we participate and work in teams, committees, and we develop a lot of our daily tasks in groups. From eating or exercising, sharing with friends, or collaborating, all of these scenarios include dynamic group behavior. In addition, businesses are conducted in groups, with two or more people, who have the expectation of some future negotiation [11]. McGrath emphasizes that groups are the social aggregates that imply the knowledge and potential of mutual interaction, so when talking about groups, complex systems must be kept in mind. Groups are complex systems, since they need many characteristics in order to define their behavior. [2] sustain that the process and activity cycle, reproduce and adjust the dynamic links and coordinate networks among others, these behaviors have motivated a century of research dedicated to the study of these phenomena, which have yielded abundant results on specific characteristics and processes in groups. [11] also emphasizes that the treatment of groups is not a simple but rather highly complex conformation, since it has many characteristics taken from the general theory of complex systems, the handling of complexity and the theory of chaos.

The first investigations into the conformation of the groups refer us back to the 1920 s and highlight the relationship between certain social groups and their own social environment, stimulated undoubtedly by the methodological orientations of the time. A large proportion of psychological studies on social groups are provided by behavioral theory and learning theory. The processes of team formation mainly emphasize four aspects: Motivational basis, organizational structure, emergence of value systems, and production of differential effects on individuals. In relation to the motivation that pushes individuals to group together, their personal qualities, goals or attitudes are considered.

We have to emphasizes that the interaction of individuals through a certain period of time gives rise to the appearance of habitual behaviors that generate patterns of groups behavior. The same ones that 
are influenced in the execution of collective tasks, that determines the characteristics of the leadership in a group with certain ways of doing and behaving that become norms, breaking the initial subjectivism in which each one faces the others from their individual characteristics and abilities.

The Artificial Intelligence emerge how a computational field with the aims of support the making decision processes. Several researchers have presented the team formation proposals using artificial intelligence paradigms. [14] presented a framework based on agreement technologies and multi-agent systems, their concluded that the framework could be used by special educational and distance education. [9] proposed a model for group formation using collective trust, their model select the "best" fitted group for a task, moreover also presents one heuristic to find the best possible group since in practice considering all the possibilities is hardly an option. [9] also point out that that this notion of collective trust is much more accurate in capturing the complexity of interactions between users than any individual based method. [1] developed computer-aided policy that facilitates the automatic generation of near optimal teams based on collective intelligence, coalition structure generation, and Bayesian learning. The proposal was tested using simulations in hypothetic classroom scenarios that show that the policy is capable of converging towards the optimal solution as long as students do not have great difficulties evaluating others. They conclude that the simulations have shown that, as long as students do not have great difficulties classifying others, the policy is capable of improving the quality of team structures in a few iterations and gradually converging towards the optimal solution.

Some others researcher has studied the useful of Collective Intelligence in the team formation process. [3] address the team formation problem for generalized tasks where a set of experts is to be discovered from an expertise social network that can collaborate effectively to accomplish a given task. In the other hand [8] presented a reflexive paper where they analyze the decision-making process developed by the ' wisdom of crowds'. They conclude it is very difficult to achieve the wisdom of crowds in environments where observational correlation is manifested. Instead, the group's decision often follows the high correlation information source, even when only a minority of the group uses this information.

The previous paragraphs have shown that exists a lot of methods have been developed by researchers from different knowledge currents, however, the mix of human collective intelligence and computation intelligence in the state of art are scarce, therefore in this study we propose a first approach of team formation groups using, the collective intelligence, psychological individual profiles and the ICT tool how media..

\section{PROPOSAL MODEL}

With the general idea of encourage the formation of work groups by evaluating objective variable of performance of its members focused on problem solving, a prototype of ICT tool and refining process has been designed, developed and formally presented in this section (Fig.1). The proposal model allows teachers, students and groups, actively participate in the process of team formation focus on the reduction of assortative mixing or homophily into the class.

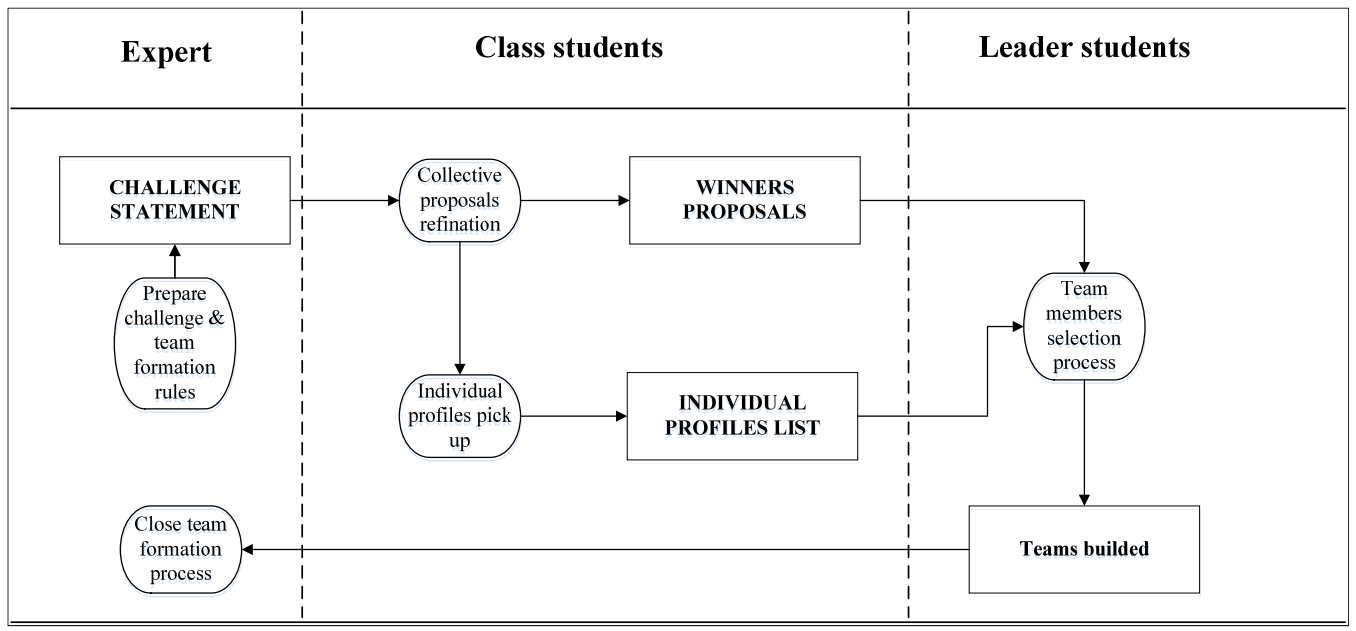

Figure 1.Team formation model 
The proposed model tries to resolve two fundamental aspects in the teams formation, in first place the leader selection, and after that the team members selection. In the next paragraph, the process is brief summarized.

The model is split into four sub-processes (Section 2.1). It's combines both the individual profiles and performance. The individual profiles are measured through a set of psychological tests (Table 3) according to sub process presented in Fig 2a. This tries to reveal some individual patterns that will be analyzed by the leader's team in the member selection sub process (Fig. 2c). The individual performance and leader selection is developed according to results from ideas management and assessments process (Fig. 2b). The process presented in Fig. 2b, was adapted from the work presented by [13]. Finally, the "Team members selection process" allow to the author of proposal that gotten one position in the Top (n), become a leader. This leader should be selecting the members for develop his project according to Fig 2c.

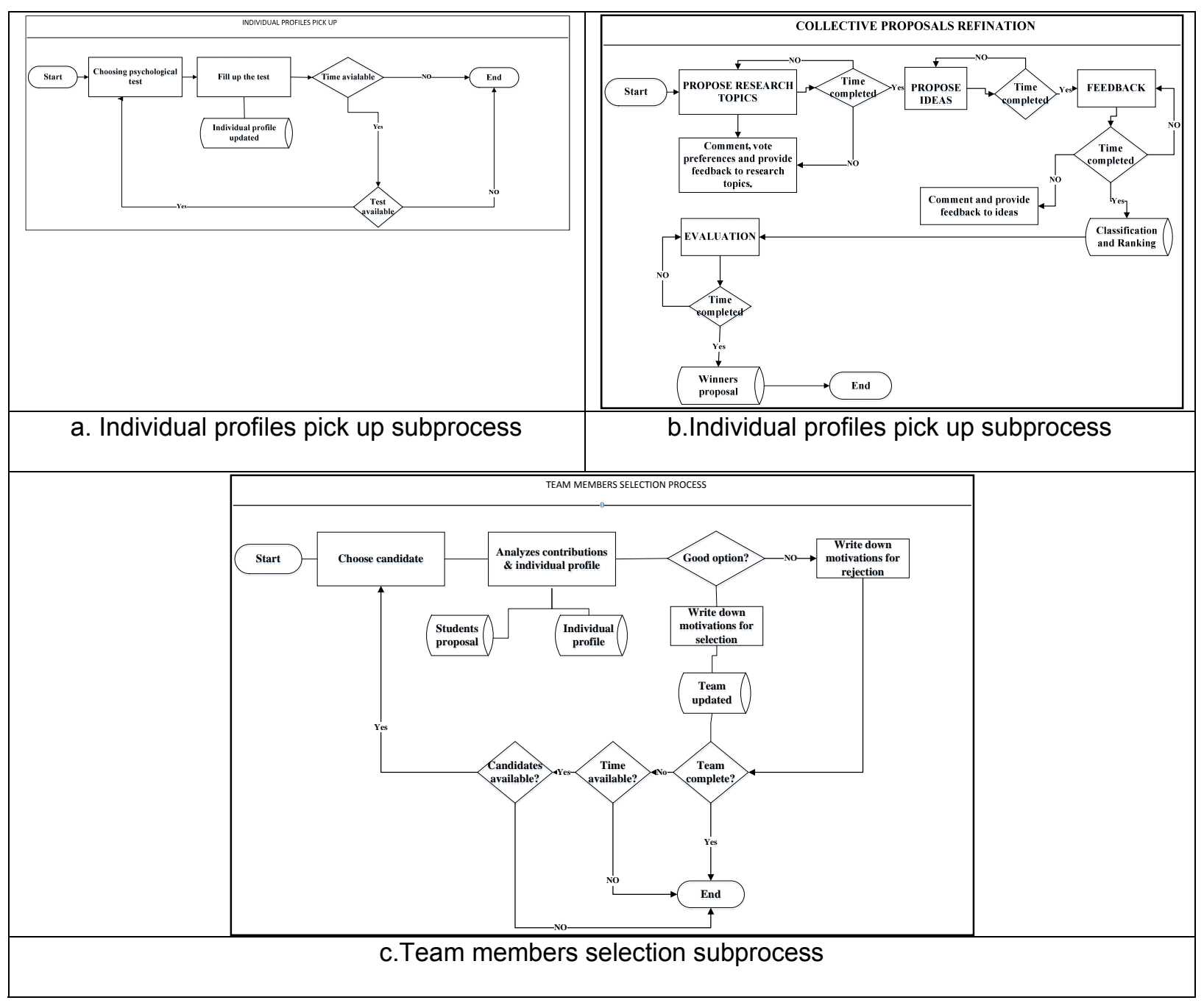

Figure 2.Sub-processes of team formation model

\subsection{Model sub-processes}

\subsubsection{Prepare challenge \& team formation rules}

The expert (s) define an area of general interest (For instance : Educational Projects) where it is required to seek for possible problem research areas as well as determine the allocated time for the fulfillment of each of the challenge stages. The area of general interest should be defined in a question mode, for instance: What is the future the higher education in Ecuador? Where are the best places for to play soccer in Ecuador? Whose are the main causes for low performance in the sports? Furthermore, the expert must set up parameters about the number of member by team, time for each stage, rubrics (Table 3) \& evaluations scales (Table 4) for each proposal, psychological tests for measure the individual profiles (Table 3 ), and the numbers of teams in the class. 
Table 1. Recommended rubrics for evaluation

\begin{tabular}{|c|c|}
\hline Rubric & Description \\
\hline Novelty & The thing is new, it exists, it is known or used for a short time. \\
\hline Added Value & $\begin{array}{l}\text { The proposal generates added value or contributes to the solution of the problem } \\
\text { like never before. }\end{array}$ \\
\hline Innovation & The presented novelty can become a reality. \\
\hline Inspirer & The proposed content inspires new ideas and it can extend the discussion topic. \\
\hline Appropriate & It is suitable for the solution of the analyzed problem. \\
\hline Complete & The content is complete and it can be easily understood. \\
\hline
\end{tabular}

Table 2. Recommended emotional evaluation scale

\begin{tabular}{lll}
\hline Emotion & Description & Value \\
\hline Dissapointment & I feel a little bad. The proposal is disappointing. & 3 \\
Rage & It's terrible. It is the worst proposal I have ever listened about. & 1 \\
Anger & There is no effort. It is bad. I do not think it helps to anything. & 2 \\
Sadness & It might be better with a little more effort. & 4 \\
Joy & I really like it. It makes me happy and I think it could be put into practice. & 5 \\
Admiration & It's the best proposal I have ever read. It is excellent. & 6 \\
\hline
\end{tabular}

Table 3. Recommended psychological tests

\begin{tabular}{|c|c|}
\hline Test & Description \\
\hline $\begin{array}{l}\text { Personality } \\
\text { Questionnaire } \\
\text { HSPQ }\end{array}$ & $\begin{array}{l}\text { It measures fourteen first order and four second order personality traits. The } \\
\text { fourteen scales point to dimensions whose functionally independent nature have } \\
\text { been established through factorial inquiry, yet each is more than a factorial scale, } \\
\text { represents a construct that has been shown to have general value as a } \\
\text { psychologically significant structure within the personality, as well We must } \\
\text { understand the strength of the superego (G-scale), dominance (E), emotional } \\
\text { stability or strength of the self }(\mathrm{C}) \text { or suggestion of temperament }(\mathrm{F}) \text {. }\end{array}$ \\
\hline $\begin{array}{l}\text { Kolb Learning } \\
\text { Styles Test }\end{array}$ & $\begin{array}{l}\text { It measures the style of learning, is the result of the way people perceive and then } \\
\text { process what they have perceived, that is, describing how they learn, how they } \\
\text { incorporate knowledge, and how they use this information in problem solving, } \\
\text { style Learning that each person uses depends on their inherited intellectual } \\
\text { characteristics, their physical experience and social interaction, is based on a } \\
\text { categorization of four learning styles: "convergent", "divergent", "assimilator" and } \\
\text { "usher". }\end{array}$ \\
\hline $\begin{array}{l}\text { Lynn O'Brien } \\
\text { Learning } \\
\text { Channel Test }\end{array}$ & $\begin{array}{l}\text { It allows individuals to identify a preference for "channel" to assimilate knowledge } \\
\text { and the one that scores the most is the one that predominates. }\end{array}$ \\
\hline $\begin{array}{l}\text { Reading the Mind } \\
\text { in the Eyes test }\end{array}$ & $\begin{array}{l}\text { Test develop by [5], for to measure of adult mentalising. This test has been } \\
\text { applied in several experience related with collective intelligence measure applied } \\
\text { for getting the level of social sensitivity [6][16][4][16]. In this test, a participant is } \\
\text { presented with a series of } 35 \text { photographs of the eye-region of the face of different } \\
\text { actors and actresses, and is asked to choose which of four words best describes } \\
\text { what the person in the photograph is thinking or feeling. }\end{array}$ \\
\hline $\begin{array}{l}\text { Team Equilibrium } \\
\text { (TE) }\end{array}$ & $\begin{array}{l}\text { TE is a model that can be used as a basis to develop tools that helps teams for } \\
\text { self-analysis. Its proposed framework is based on six thinking hats proposed by } \\
\text { (de Bono, 1985) with aim to face a situation and solve a problem. Each hat should } \\
\text { be applied during the solving problem process because it represent a different } \\
\text { way to think and thus can be considered as a thinking direction[7]. }\end{array}$ \\
\hline
\end{tabular}

\subsubsection{Collective proposals refination}

Propose research topic.- Each one of the participants are enlisted in the suggested challenge and during the assigned time to the challenge, they propose possible topics that present potential problems within the context of the challenge. Each participant in this process can propose as well as to make comments and vote for their preferences on the proposals submitted by other participants, encouraging a constant feedback. 
Ideas.- In one or more topics of interest, even in those proposed by the same participant, solution ideas are prosed to the selected topics. The design of the proposal includes: a title of the solution, a short explanation on how to do it, besides, if required, a short essay of ideas, as well as videos and annexes that support the proposal could be included.

Feedback.- When the phase of ideas is finished, participants come with the first iteration of quantitative refinement. Each participant makes a vote (I like it / I do not like it) on each one of the ideas proposed as a solution, except on the own ones. They can also comment and provide feedback on the proposals of solutions to improve them. Comments include a brief description and, if necessary, a report that includes videos, images, etc. As a result of this process, a ranking of preferences of ideas is generated. The ideas that go to the next stage are classified according to number of teams by the class. We have to point out that in the case that one student have more than one proposal in the list of ranking, the platform only select the first.

Evaluation.- The ideas that exceeded the preference ranking, come to be valued by the / the expert (s) as well as the participants as well as the proponent of the idea. The rating scale is done according to a set of rubrics. Each item is evaluated by the emotion caused on the evaluator (participant / expert) in accordance to the scale criteria defined.

Winners proposal.- Upon completion of the period of time assigned for the assessment, the final ranking of solution proposals is generated, for the team members selection and the subsequent application.

The main interfaces of collective proposals refination subprocess are presented in Appendix I. Fig. 3.

\subsubsection{Individual profiles pick up}

Choosing psychological test.- The student have to selecting one by one the psychological tests available.

Fill up the test.- During the time assigned each student must to filling up the selected test. The test filled up will be show to team leader for the team member selection.

\subsubsection{Team members selection process}

Choose candidate.- Choose available candidate from the list, the list only present a code without any signal about the member identification (Appendix I. Fig 4a).

Analyzes contributions \& individual profile.- Reading and analyzing: Proposal topic, ideas and vote criteria, additionally the individual profile. (Appendix I. Fig 4b).

Write down motivations for selection/Rejection.- Selecting or rejecting if the analyzed member is adequate or no adequate for your team. Only when you choose a member his/her personal information is presented.

\section{EMPIRICAL EXPERIENCE \& RESULTS}

\subsection{Empirical experience settings}

In this section, the empirical evidence of TBT application through a web tool (Appendix I) is described. TBT was used by one group of student from the University of the Armed Forces of Ecuador ESPE in the academic year 2016-2017 in the months of November and December of 2016. The number of students were 24 (18 Masculine, 6 Feminine) the average of age was 20 years age. The students had to resolve the challenge addressed by the question "What is the best solution to improve some issues into the physical training field in Ecuador?" .Therefore they had to execute the list of task presented in Table 4.

Table 4. List of task applied with the proposal model

\begin{tabular}{lllll}
\hline Task & Content & Executer & Start & Finish \\
\hline Prepare challenge \& & Challenge.- What is the best solution to & Expert & Nov-15 & Nov-20 \\
team formation rules & $\begin{array}{l}\text { improve some issues into the physical } \\
\text { training field in Ecuador?" }\end{array}$ & & & \\
& Rubrics.- According Table 1. & & & \\
\end{tabular}


Evaluations scales.- According Table 2

Psychological tests.- According Table 3.

Numbers of teams.- Six teams, therefore

also the top list is six.

\begin{tabular}{|c|c|c|c|}
\hline \multicolumn{2}{|c|}{ Individual profiles pick up } & \multicolumn{2}{|l|}{ Student of class } \\
\hline $\begin{array}{l}\text { Choosing } \\
\text { psychological test }\end{array}$ & $\begin{array}{l}\text { Selecting one by one the psychological } \\
\text { tests available. }\end{array}$ & Nov-21 & Nov-28 \\
\hline Fill up the test & Filling up the selected test & Nov-21 & Nov-28 \\
\hline \multicolumn{2}{|c|}{ Collective proposals refination } & Student of class & \\
\hline $\begin{array}{l}\text { Propose research } \\
\text { topic }\end{array}$ & $\begin{array}{l}\text { Have to search for possible topics of } \\
\text { interest in the area of challenge that may } \\
\text { require a solution (eg feeding in infants, } \\
\text { sports development in early childhood, etc.). } \\
\text { To execute this task each of you will } \\
\text { propose at least one topic of interest } \\
\text { (several of your interests are } \\
\text { recommended) and will present your } \\
\text { comments in several and vote according to } \\
\text { your preferences (I like or dislike) }\end{array}$ & Nov-21 & Nov-23 \\
\hline Ideas & $\begin{array}{l}\text { A list of top topics has been generated } \\
\text { according to the preferences of student's } \\
\text { votes. In one or several topics of interest } \\
\text { even in those proposed by the same } \\
\text { participant, ideas are proposed for solving } \\
\text { the topic selected or how to apply general } \\
\text { topic to our local context. Ex: If you are } \\
\text { talking about creative classrooms, propose } \\
\text { possible options on how to apply it locally. } \\
\text { The design of the proposal includes a title of } \\
\text { the solution, a short explanation of how to } \\
\text { do it, besides requiring a brief essay of the } \\
\text { ideas, as well as videos that support the } \\
\text { proposed solution to the problem identified } \\
\text { in the topic of interest selected }\end{array}$ & Nov-24 & Nov-25 \\
\hline Feedback & $\begin{array}{l}\text { After the ideas, the participants proceed } \\
\text { with the first iteration of quantitative and } \\
\text { qualitative refinement (comments to } \\
\text { improve the idea). Each participant makes a } \\
\text { vote (I like / do not like) about each of the } \\
\text { suggested solution ideas except yours; The } \\
\text { result of this process generates a ranking of } \\
\text { ideas preferences. The ideas that go to the } \\
\text { next stage are classified according to a Top } \\
\mathrm{N} \text { ( } \mathrm{N} \text { is the number of teams for the class) }\end{array}$ & Nov-26 & Nov-26 \\
\hline Evaluation & $\begin{array}{l}\text { Ideas that surpassed the top } \mathrm{N} \text { of } \\
\text { preference, proceeds to be valued by the } \\
\text { expert (s) as well as of the participants still } \\
\text { the proponent of the idea. The rating scale } \\
\text { is made according to a set of rubrics defined } \\
\text { previously. }\end{array}$ & Nov-27 & Nov-28 \\
\hline Winners proposal & $\begin{array}{l}\text { The Top } \mathrm{N} \text { of proposals will be presented. } \\
\text { The team leader will be the owner of each } \\
\text { proposal; therefore, they should be starting } \\
\text { the team members selection in the assigned } \\
\text { date. }\end{array}$ & Nov-29 & Nov-29 \\
\hline \multicolumn{2}{|c|}{ Team members selection process } & Team Leader & \\
\hline Choose candidate & $\begin{array}{l}\text { Choose available candidate from the list, } \\
\text { the list only present a code without any } \\
\text { signal about the member identification. }\end{array}$ & Dic-05 & Dic-05 \\
\hline
\end{tabular}




\subsection{Results}

Table 5. Group selection results.

\begin{tabular}{|c|c|c|c|c|c|}
\hline Id & Proposal & & & Team Profile Interpretation & $\begin{array}{l}\text { Team members } \\
\text { selection criteria }\end{array}$ \\
\hline 1 & $\begin{array}{l}\text { High performance } \\
\text { improves overall } \\
\text { development }\end{array}$ & 2 & 2 & $\begin{array}{l}\text { The learning channel that } \\
\text { predominates is visual, followed by } \\
\text { the auditory, all belong to a } \\
\text { Divergent - concrete learning style, } \\
\text { the same ones that have the ability } \\
\text { to separate a whole into parts but } \\
\text { being precise and real. With varying } \\
\text { personality types, while in second- } \\
\text { order personality, they mostly } \\
\text { belong to an introverted trait and few } \\
\text { of the members are anxious traits. }\end{array}$ & $\begin{array}{l}\text { The interests of the } \\
\text { members in the } \\
\text { proposals submitted } \\
\text { and in their voting were } \\
\text { related to the high- } \\
\text { performance } \\
\text { processes. }\end{array}$ \\
\hline 2 & $\begin{array}{l}\text { APP for physical } \\
\text { training }\end{array}$ & 3 & 1 & $\begin{array}{l}\text { The learning channel is diverse } \\
\text { (Visual, Auditory, Kinesthetic), so } \\
\text { that the leader must use the } \\
\text { necessary tools to consolidate his } \\
\text { team. Its main objective is } \\
\text { innovation. }\end{array}$ & $\begin{array}{l}\text { Selection according to } \\
\text { the individual profiles, } \\
\text { focused mainly in } \\
\text { relation to creativity, } \\
\text { optimism and } \\
\text { management ability. }\end{array}$ \\
\hline 3 & $\begin{array}{l}\text { Disc- } \text { Recreational } \\
\text { golf for hearing } \\
\text { impaired }\end{array}$ & 3 & 1 & $\begin{array}{l}\text { The group has a predominant } \\
\text { learning channel such as the visual, } \\
\text { accompanied by a divergent thought } \\
\text { reflective, with the ability to use } \\
\text { different senses. In most members } \\
\text { Their personality varies, belong to a } \\
\text { group of calm individuals, few of } \\
\text { them are affected by their emotions } \\
\text { and their environment. }\end{array}$ & $\begin{array}{l}\text { Combined the } \\
\text { individual profiles with } \\
\text { emphasis on optimism } \\
\text { and research capacity, } \\
\text { as well as collaboration } \\
\text { in the process of } \\
\text { refining ideas. }\end{array}$ \\
\hline 4 & Working small space & 4 & 0 & $\begin{array}{l}\text { With } 50 \% \text { visual learning channel } \\
\text { and } 50 \% \text { kinesthetic learning } \\
\text { channel, mostly their type of thinking } \\
\text { is divergent concrete, few of them } \\
\text { are the same adapters that have the } \\
\text { ability to change, modify or adjust } \\
\text { things, in His personality there are } \\
\text { variety, stable, little expressive, } \\
\text { among others. }\end{array}$ & $\begin{array}{l}\text { The interests of the } \\
\text { members in the } \\
\text { proposals presented } \\
\text { and in their votes were } \\
\text { related to the proposal. }\end{array}$ \\
\hline 5 & $\begin{array}{l}\text { Women's } \\
\text { with } \\
\text { method }\end{array}$ & 2 & 2 & $\begin{array}{l}\text { Channels of different learning, they } \\
\text { make their thoughts vary, with } \\
\text { different personality traits. }\end{array}$ & $\begin{array}{l}\text { Similar Interests in the } \\
\text { proposals presented. }\end{array}$ \\
\hline 6 & $\begin{array}{l}\text { Women's } \\
\text { with } \\
\text { Schedules }\end{array}$ & 4 & 0 & $\begin{array}{l}\text { It has diverse learning channels, } \\
\text { they make their thoughts vary, with a } \\
\text { different personality trait }\end{array}$ & $\begin{array}{l}\text { Similar Interests in the } \\
\text { proposals presented. }\end{array}$ \\
\hline
\end{tabular}

\section{CONCLUSIONS}

The objective of the presented work is to share the progress on a research program, which purpose is to provide a process, tools and resources for fostering the reduction of assortative mixing or homophily 
into the class in the teams formation process. The teams formation has a very broad and open conceptual framework and more theoretical and empirical research is necessary to generalize the application of the model.

The application of TBT has shown evidence on the usefulness of the model in the reduction of assortative mixing or homophily into the class. The usefulness of the model is considered because the evaluation according to the contributions, preferences and individual member's profiles, presents a new field for evaluation in the educational area, that combine the individual \& collective human intelligence and the computational intelligence for making the best decision.

Although the students analyzed have personal interests and their main objective is to satisfy their own needs not the needs of their team, we have to remember the link between body, mind and spirit would help in the formation of a whole human being, using emotional intelligence strategies, collaborative work and ICT's, essential components for his or her formation. In this sense, future research should cover this fields, additionally combine the result of team with a collective intelligence measure, that allow analyzed in deep the affectivity of model with quantitative results.

The proposed model and the corresponding web tool are the result of a creative combination of theoretical and practical perspectives. From this point, with a consistent model, it will be possible to continue with the development of new features oriented to make recommendations on the continuous improvement to the state of art in the field of reduction of assortative mixing or homophily into the class, that combine the collective human intelligence and computational intelligence.

\section{ACKNOWLEDGEMENTS}

We thank the Department of Human and Social Sciences of the University of the Armed Forces ESPE (ECUADOR).

\section{REFERENCES}

[1] Alberola, J. M., Val, E., Sanchez-anguix, V., \& Julian, V. (2013). Simulating a Collective Intelligence Approach to Student Team Formation. Springer-Verlag Berlin Heidelberg 2013, 6, 161-170.

[2] Arrow, H., McGrath, J. E., \& Berdahl, J. L. (2000). Groups as Complex System. In I. E. 0002 (16 de mayo de 2000) SAGE Publications (Ed.), Small Groups as Complex Systems: Formation, Coordination, Development, and Adaptation (p. 56,57).

[3] Awal, G. K., \& Bharadwaj, K. K. (2014). Team formation in social networks based on collective intelligence - An evolutionary approach. Applied Intelligence, 41(2), 627-648. http://doi.org/10.1007/s10489-014-0528-y

[4] Barlow, J. B., \& Dennis, A. R. (2014). Not as Smart as We Think: A Study of Collective Intelligence in Virtual Groups. In Collective Intelligence 2014 (pp. 1-5).

[5] Baron-Cohen, S., Wheelwright, S., Hill, J., Raste, Y., \& Plumb, I. (2001). The "Reading the Mind in the Eyes" Test revised version: a study with normal adults, and adults with Asperger syndrome or high-functioning autism. Journal of Child Psychology and Psychiatry, and Allied Disciplines, 42(2), 241-51. http://doi.org/10.1111/1469-7610.00715

[6] Engel, D., Woolley, A. W., Jing, L. X., Chabris, C. F., \& Malone, T. W. (2014). Reading the mind in the eyes or reading between the lines? Theory of mind predicts collective intelligence equally well online and face-to-face. PLoS ONE, 9(12), 1-16. http://doi.org/10.1371/journal.pone.0115212

[7] Ferruzca, M., Rodrigues, J., Monguet, J. M., \& Trejo, A. (2013). Team Equilibrium and Innovation Performance. IEEE, 30-36. http://doi.org/978-1-4799-1542-2

[8] Kao, A. B., \& Couzin, I. D. (2014). Decision accuracy in complex environments is often maximized by small group sizes. Proceedings. Biological Sciences / The Royal Society, 281(1784), 20133305. http://doi.org/10.1098/rspb.2013.3305

[9] Largillier, T., \& Vassileva, J. (2012). Using Collective Trust for Group Formation. Springer-Verlag Berlin Heidelberg, 137-144. 
[10] Laura Guerra, Francisca Grimon, Mirella Herrera, J. M. (2013). Behavioral analysis model for sharing knowledge in virtual groups Laura. AWERProcedia Information Technology \& Computer Science, 3, 335-340.

[11] McGrath, J. E. (1983). Groups and Human Behavior. In D. A. Josephson (Ed.), Groups: Interaction and Performance (pp. 5-6). ILLinois: Prentice - Hall, Inc.; Englewood Cliffs, New Jersey.

[12] McGrath, J. E., Arrow, H., \& Berdahl, J. L. (2000). The Study of Groups: Past, Present, and Future. Personality and Social Psychology Review, 4(1), 95-105. http://doi.org/10.1207/S15327957PSPR0401_8

[13] Meza, J., Ortiz, O., Vaca-Cardenas, M., Roman, S., \& Monguet, J. M. (2017). CIR: Fostering Collective Creativity. In G. Vincenti, A. Bucciero, M. Helfert, \& M. Glowatz (Eds.), E-Learning, EEducation, and Online Training: Third International Conference, eLEOT 2016, Dublin, Ireland, August 31 -- September 2, 2016, Revised Selected Papers (pp. 145-152). Cham: Springer International Publishing. http://doi.org/10.1007/978-3-319-49625-2_18

[14]Pajares, S., Torreño, A., \& Esparcia, S. (2011). A Novel Teaching-Learning Strategy for Teamwork based on Agreement Technologies, 21-30.

[15] Woolley, A. W., Aggarwal, I., \& Malone, T. W. (2015). Collective intelligence and group performance. Current Directions in Psychological Science, 24(6), 420-424. http://doi.org/10.1177/0963721415599543

[16] Woolley, A. W., Chabris, C. F., Pentland, A., Hashmi, N., \& Malone, T. W. (2010). Evidence for a collective intelligence factor in the performance of human groups. Science (New York, N.Y.), 330(6004), 686-8. http://doi.org/10.1126/science.1193147

\section{APPENDIX I. Web tool interfaces}

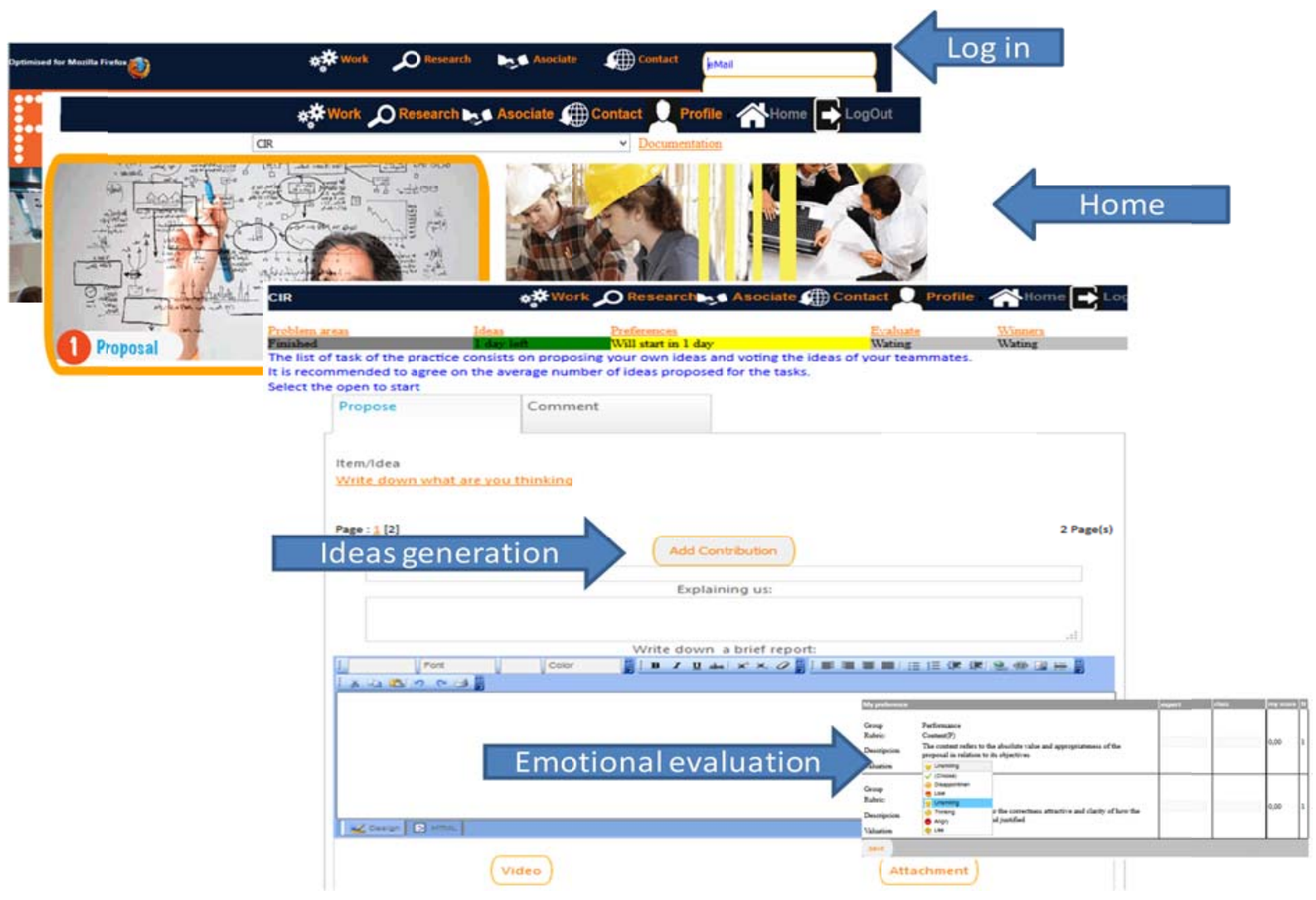

Figure 3. Main interfaces of collective proposals refination subprocess 


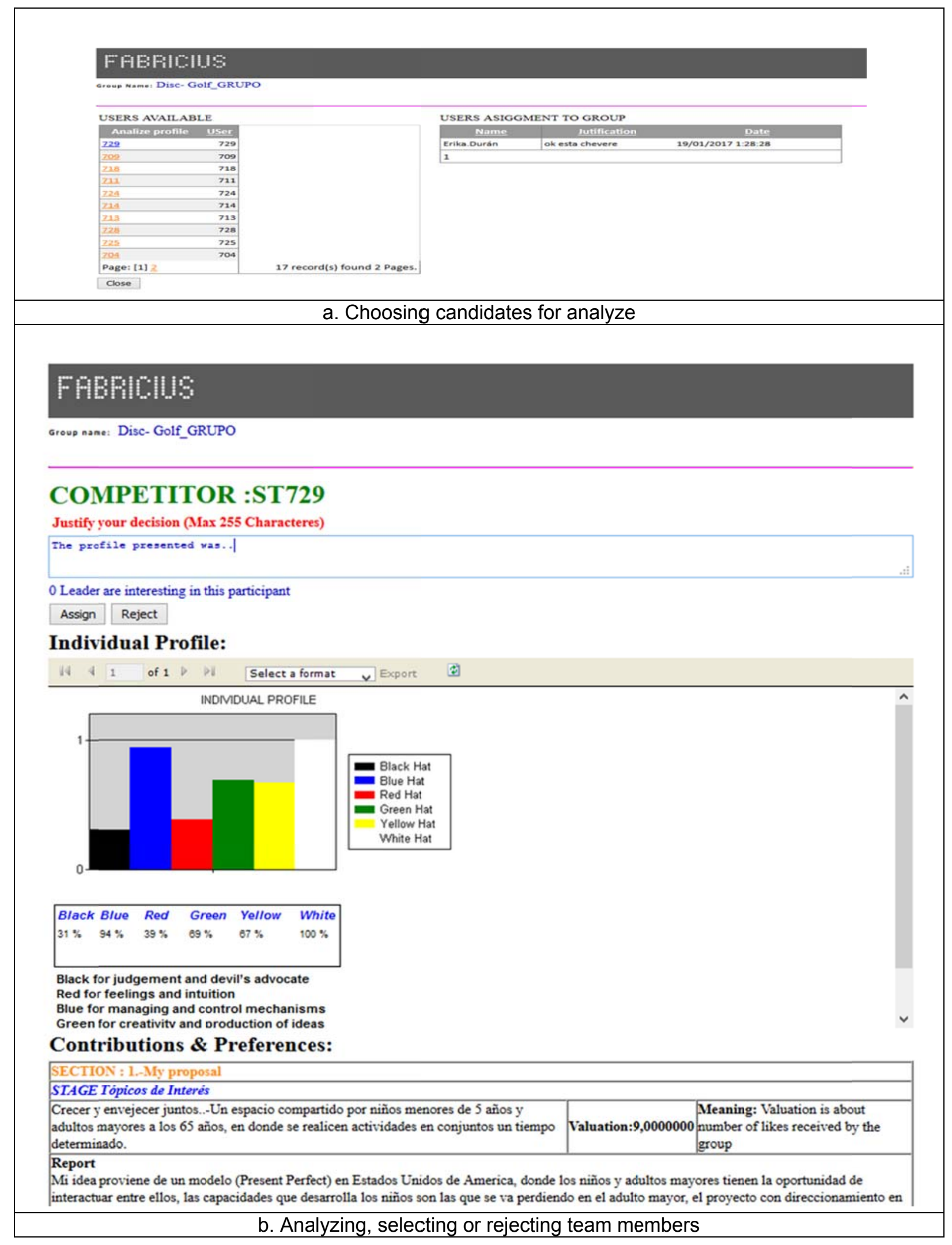

Figure 4. Main interfaces of team members selection subprocess 